\title{
SUPPLY NETWORK DELEGATION AND INTERVENTION STRATEGIES DURING SUPPLIER INVOLVEMENT IN NEW PRODUCT DEVELOPMENT
}

\author{
Dr Thomas E. Johnsen \\ Associate Professor in Purchasing \& Supply Management \\ Centre of Purchasing \& Supply Chain Atlantique (PASCA) \\ Audencia Nantes School of Management, \\ 8 Route de la Joneliere, \\ BP 31222 - 44312 Nantes Cedex 3, France. \\ E-mail: tjohnsen@audencia.com \\ Tel: + $33(0) 240374625$ \\ Fax: +33 (0)2 40373407
}

\begin{abstract}
Purpose - This paper proposes and empirically investigates two strategies that companies can employ to involve indirect suppliers in new product development: supply network delegation and supply network intervention. The implications of the two strategies are explored.

Design/methodology/approach - The paper brings together the traditional new product development literature, organizational behaviour and organizational economics literature, and reports on three in-depth case studies of new product development projects, involving 39 semi-structured interviews across three supply networks.

Findings - Findings reveal different manifestations of the two strategies of supply network intervention and delegation, when applied as part of supplier involvement in product development, and positive and negative indications of delegation and intervention, depending on the actor perspective: manufacturers perceive a need to control the product development process across several supply network tiers through intervention in supplier selection and communication, but these actions are likely to 'tie the hands of the suppliers'.
\end{abstract}


Practical implications - Managers are advised to explicitly delegate decisions to suppliers, for example, by issuing parts approval lists and encouraging communication and problem solving amongst suppliers, and to exercise caution in applying the intervention strategy.

Originality/value - The paper contributes to a better understanding of how to involve indirect (sub-) suppliers in product development, and the implications of these actions for multiple supply network actors.

Keywords: Supply networks, supplier involvement, delegation, intervention, product development

Paper type: Research paper

\section{Introduction}

Suppliers are important to consider as partners in new product development (NPD) projects, because they provide access to specialized design and development capabilities. Indeed, a substantial body of literature on supplier involvement in NPD has evolved over the last 25 years or so (Imai et al., 1985; Clark and Fujimoto, 1991; Wasti and Liker, 1997; Petersen et $a l ., 2005)$, suggesting that early and extensive involvement of key suppliers in NPD projects is critical for NPD success.

However, there are many management challenges associated with achieving performance benefits from supplier involvement (Hartley et al., 1997; Eisenhardt and Tabrizi, 1995; Karlsson et al., 1998; Van Echtelt et al., 2008). One of these challenges is for companies to look beyond their immediate first tier suppliers and consider how they can exploit their wider supply network (Staudenmayer et al., 2005). This is pertinent in increasingly dynamic and 
complex industries, which necessitate that a range of complementary technologies and capabilities are incorporated into innovative product/service offerings. Yet there is a paucity of research that has examined the strategies that companies can employ to access the indirect suppliers that reside in their wider supply network, for example in terms of how they delegate NPD responsibilities and in which ways they seek to intervene in NPD decisions within supply networks. This is important both because the performance of direct suppliers depends on lower tier suppliers and because sources of innovation often stem from distant relationships within the wider network (Håkansson, 1987; Birkinshaw et al., 2007). Identifying the most appropriate ways of exploiting the wider supply network for improved NPD performance through delegation and/or intervention is therefore a theoretical and a practical research imperative. This paper seeks to contribute to existing research by exploring the manifestations and implications of supply network strategies when applied as part of supplier involvement in NPD. The research questions driving this study were:

1. In what ways are supply network intervention and delegation strategies manifested during supplier involvement projects?

2. What are the multi-actor implications of supply network intervention and delegation strategies for the processes of supplier selection and communication during supplier involvement projects?

The paper builds on and brings together the traditional NPD literature and the literature on managerial intervention and delegation found in the organizational behaviour and organizational economics literature. Bringing together these two literatures furthers our understanding of involving supply networks, rather than merely direct suppliers, in NPD. In 
particular, this contributes to understanding the concepts of delegation and intervention strategies.

The paper is organized as follows. The following section reviews research into supplier involvement in NPD focusing on the role of supplier selection and communication. The third section defines the concepts of delegation and intervention and discusses how these can be applied in a supply network context. The fourth section outlines the methodology and the fifth section reports the findings from three in-depth case studies of supply network delegation and intervention during NPD projects. The sixth section discusses the findings on delegation and intervention strategies. Section seven discusses the different manifestations of delegation and intervention strategies and section eight outlines the conclusions.

\section{Supplier involvement in NPD}

There is a flourishing body of research that has developed and tested how companies can make the most of supplier involvement in NPD. Selecting the right suppliers has been identified as one key success factor. Suppliers should have strong complementary technical capabilities (Hartley et al., 1997; Petersen et al., 2005) and agree technical metrics and targets. Furthermore, Ragatz et al. (1997) identified the role of shared training, trust, risk and reward sharing, agreed performance measurements, top management commitment and supplier capability confidence. Likewise, Petersen et al. (2003) suggested that supplier representation on NPD development teams is critical. LaBahn and Krapfel (2000) further pointed out that the power dynamics within buyer-supplier relationships should not be underestimated and that powerful customers, who behave opportunistically, may ruin the 
trust and commitment that have taken a long time to evolve (see also Cousins and Crone, 2003). Development of trust and commitment is therefore a pre-condition for successful supplier involvement in NPD.

Open and frequent knowledge sharing and communication is a recurring theme in the supplier involvement literature Littler et al. (1995) found that frequent inter-company communication increased the likelihood of success. Ragatz et al. (1997) further identified direct and cross-functional inter-company communication as the most widely used technique for supplier integration in NPD (see also Petersen et al., 2003; Wasti and Liker, 1997). Similarly, in Takeishi's (2001) study of Japanese automakers and suppliers, frequent face-toface communication and early integrated problem solving were found to positively affect design quality. Recently, Lawson et al. (2009) reported on a study of knowledge sharing in inter-organizational NPD teams; they found knowledge sharing to be positively associated with NPD performance, and that formal and informal socialization mechanisms facilitated knowledge sharing and the development of trust within buyer-supplier relationships.

Various authors highlighted the need for a supplier involvement typology, segmenting the level of involvement according to, for example, the level of supplier responsibility and development risk (Wynstra and ten Pierick, 2000; Petersen et al., 2005). Similarly, Fliess and Becker (2006) emphasized how supplier integration, coordination and communication differ according to the type of supplier involvement i.e. contractual, coordinated or joint development, and the development stage. However, even using classifications most research on supplier involvement in NPD focuses on dyadic relationships between manufacturers and their direct suppliers. Yet there is a strong and long-established body of research, which emphasizes the need to understand the embeddedness of dyadic relationships in wider 
industrial networks (e.g. Ford et al. 2003; Håkansson, 1987). This raises the question of how companies can involve not only their direct suppliers, but also those that exist within their wider supply networks.

\section{Supply network intervention and delegation strategies}

This study focuses on the role of supply network delegation and intervention as ways to involve indirect suppliers in NPD. Although the concepts of intervention and delegation are not new to the wider management literature, little research appears to have been conducted within the realms of NPD. Therefore, the next section briefly reviews research on intervention and delegation in the general management literature, particularly the fields of organizational behaviour and economics. Combined with the more traditional NPD literature, this body of literature is used to explore the role of supply network intervention and delegation strategies during supplier involvement in NPD.

\subsection{Managerial intervention and delegation}

Delegation is a widely used concept in management theory and can be broadly defined as 'the process of entrusting authority and responsibility to others throughout the various levels of the organization, and the creation of a special manager-subordinate relationship' (Mullins, 2005, p.1053). Intervention is a more difficult concept to pin down: it tends to imply interference in someone else's business and therefore often has a negative association, although managerial intervention can also be regarded more positively. 
Discussing the implications of managerial intervention at firm-level, Foss et al. (2006, pp. 798-799) argued that firms rely on both managerial authority and employee discretion; while some degree of authoritative action is required through intervention, 'discretion may be rationally delegated to employees to the extent that it stimulates motivation and fosters local learning and the use of local knowledge'. Similarly, authors in organizational economics have examined the concepts of authority and delegation (Williamson, 1970; Simon, 1951). Organizational economists usually view both delegation and intervention as beneficial, although it is recognized that there may also be negative outcomes associated with both. Various mechanisms including implicit contracts (Baker et al., 1999) and explicit credible commitments (Brockner et al., 1992) have been proposed as ways to reduce the incidence and severity of harmful managerial interventions.

Organizational behaviourists tend to view delegation as a matter of 'empowerment' (Conger and Kanungo, 1988; Thomas and Velthouse, 1990). Empowerment suggests that increasing the delegation and discretion to employees often 'raises the perceived self-determination of employees and therewith strengthens intrinsic motivation' (Osterloh and Frey, 2000, p. 543), and may lead to increased creativity in pursuit of goals (Foss et al., 2006). In comparison with intervention, delegation therefore usually has a positive connotation, although it may also have a downside if employees do not appreciate or feel competent to command such discretion (Mowday et al., 1982).

Williamson (1996, pp. 150-151) suggested that the option to intervene 'can be exercised both for good cause (to support expected net gains) and for bad (to support the subgoals of the intervenor)'. It follows that although intervention may be perceived as a positive action, it often has negative associations, especially when the intervenor lacks credibility (Williamson, 
1993). The notion of intervention for a bad cause implies managerial opportunism (Williamson, 1996), and suggests that there are costs as well as benefits to deploying managerial authority through intervention. Inspired by the ancient expression of 'tying the king's hands' (Root, 1989), Foss et al. (2006) neatly characterized opportunistic managerial intervention as a way of 'tying the manager's hands', and concurred with Williamson (1996) that it may result in sub-optimization and be damaging to overall value creation.

Intervention and delegation therefore represent alternative ways of exerting managerial authority within firms. Delegation involves empowering employees to take decisions that relate to their own work. It has been linked to increased motivation and creativity in pursuit of goals, at least in those situations where employees feel competent to command such discretion. Intervention implies managerial action and may therefore constitute a positive rational behaviour, but several authors highlight the potentially negative implication of intervention associated with managerial opportunism that can ultimately lead to 'tying the manager's hands'.

\subsection{Supply network intervention and delegation}

The concept of supply chain management (SCM) implies that focal companies manage their entire supply chain from original sources of raw materials to end customers (Lambert and Cooper, 2000). Therefore, one might expect existing research to have investigated intervention and delegation issues in a supply chain context. Yet, the majority of research on intervention and delegation concerns firm-level decision-making and not supply chain or network management. 
The increasing use of modular architectures in many industries has been described as a way to delegate design and development decisions to a small core of supply network partners (Sanchez and Mahoney, 1996; Baldwin and Clark, 1997). Standardized component interfaces in modular product systems create 'nearly decomposable systems' (Simon, 1962) and thereby reduce 'the need for overt exercise of managerial authority to achieve coordination of development processes' (Sanchez and Mahoney, ibid, p. 64). Modular product designs facilitate modular decomposed organizational designs in which decision-making is partitioned into tasks (von Hippel, 1990) that can be performed autonomously and concurrently by loosely coupled organizations (Sanchez and Mahoney, ibid). Enabling systems sourcing strategies, whereby entire systems, or modules, are sourced from large subsystem integrators, modular product designs may result in - and require - tiered supply network structures. Furthermore, product modularization is often linked to a physically proximate and closely integrated supply chain although it may paradoxically add extra tiers (Lau and Yam, 2005). In summary, modularization may enable increased delegation of design and development decisions to supply networks once manufacturers have designed the overall product architecture and component interfaces and thereby reduce the need for manufacturer intervention (Ulrich, 1995).

The concept of 'disintermediation' involves the elimination of an intermediary in a supply chain and resembles interventionist SCM thinking. Most examples of disintermediation concern on-line companies (e.g. Amazon.com) that have cut out the middle-man, and thereby created a cost and/or time advantage. 'Direct purchasing' also exemplifies supply chain intervention. Brown et al. (2005) identified direct purchasing as among the first manifestations of SCM involving analysis of the extended supply chain. It usually involves retailers buying directly from producers, and therefore exemplifies 'cutting out the middle- 
man', in relation to upstream suppliers. Johnsen and Ford $(2005,2007)$ similarly used the concept of intervention to describe the situation where the customer becomes directly involved in its indirect supplier's activities (e.g. 'second tier' suppliers), which is therefore effectively a method of disintermediation.

Lamming (1996) argued that intervention is often a case of interference, practiced because the customer does not trust the supplier to implement operational improvements on its own. This negative perception is consistent with the commonly held views of organizational behaviourists regarding firm-level intervention. Hines (1996) perceived intervention more positively, suggesting that intervention may simply be applied in cases where the customer seeks to help out an ailing supplier by applying its management skills to its operational problems.

In summary, the concepts of intervention and delegation are both well-described within organizational economics and parts of the organizational behaviour literature, which have analyzed the effects of both strategies, but predominantly at intra-firm level. SCM theory promises to adopt an end-to-end supply chain perspective, but although there are examples of supply chain studies going beyond a dyadic unit of analysis, little research has attempted to do so in the context of NPD. The focus of this paper is on the manifestations and implications of each strategy on the process of supplier involvement in NPD projects. It is particularly relevant to consider how delegation and intervention strategies affect the important processes of supplier selection and communication. For example, companies might attempt to influence supplier selection of their second or third tier suppliers. They might also communicate design ideas or concepts directly with second or third tier suppliers. But what are the implications of 
such actions? The following section outlines the research methods employed to investigate the research questions.

\section{Research method}

\subsection{Case study rationale and data collection process}

Unlike survey-based research, case studies that extend into several supply network tiers enable analysis of structural and processual inter-organizational factors from multiple respondent perspectives. Although supplier involvement is becoming well-understood by researchers in the field, the employment of supply network delegation and intervention strategies in this context is a relatively new area of study and naturally lends itself to multiple in-depth case study research (Yin, 1989; Meredith, 1998; Voss et al., 2002). For these reasons this study employed an in-depth case study research design, conducted from an interpretivist perspective (Ramsay, 1998), with focus on understanding the meaning of events and phenomena. The cases aimed to collect rich and qualitative data yet remaining rigorous by ensuring well-developed research protocols, instruments and pre-planned methods of analysis (Eisenhardt, 1989).

Prior to launching the in-depth case studies, a pilot study that involved five face-to-face interviews across five companies was conducted. These exploratory open-ended interviews helped to refine the research questions, grasp supply network strategies employed during supplier involvement projects, and thereby helped to ensure construct validity and reliability (Yin, 1989; Voss et al., 2002). Building on the lessons from the pilot study and a review of the literature, data collection for the in-depth case studies commenced. Three case studies 
were selected from two industries: automotive and telecommunications; these industries were chosen because they have been identified in other studies as typical contexts in which supplier involvement is now established best practice. Two industries were included to avoid the study being industry-specific and to improve external validity (Yin, 1989). NPD projects constituted the unit of analysis, so each project constituted a case study. All projects had either been completed recently or were nearing the launch stage.

Each project was accessed through a focal company, although interviews were conducted with several companies involved in the NPD projects in order to gain a variety of perspectives. In addition to three interviews conducted during case study facilitation, the three cases involved in total 34 semi-structured interviews with managers and directors at different levels and from a variety of functions within the focal firms and also with a selection a key suppliers and customers.

The suppliers that were interviewed were identified as 'high-involvement' suppliers by the focal firms, based on assessment of component value and risk. This 'snowballing' process (Robson, 1997) continued as far as practically feasible in each case. The focal firm customers were also interviewed where appropriate. As the interviews concerned sensitive issues all interviewees were promised confidentiality so all names of individuals and real company names have been concealed in this paper.

Each interview lasted approximately one and a half to three hours. Semi-structured interview protocols were used (Voss et al., 2002) where questions were open-ended rather than fully operationalized, so extensive discussion often took place around the formal questions (Yin, 1989). Initial interviews in each case focused on contextual issues i.e. company, project, 
customer and supplier characteristics. Supply network maps were drawn to identify the major actors involved in the project and the components or technologies they contributed; simplified version of these are shown in Figure 1. Subsequent interviews examined the process of customer-supplier collaboration within the projects and explored whether and how companies sought to intervene in and/or delegate decisions within the wider supply network. Appendix A contains an abbreviated generic version of the interview protocol.

\section{INSERT FIGURE 1 HERE}

\subsection{Analytical techniques}

The interviews were tape-recorded and subsequently transcribed. Transcripts were read and annotated providing a first level coding (Miles and Huberman, 1984). In addition, contextual factors and emerging themes raised by respondents were identified. Role-ordered matrices (Miles and Huberman, 1984) were constructed and used as coding frameworks to analyze focal actor, supplier and customer interpretations. Cross-case analysis provided external validation of the individual case study findings (Eisenhardt, 1989). Hence, patterns were identified across the cases by using cross-case comparison meta-matrices (Miles and Huberman, 1984). This process created an aggregated picture of intra- and inter-company interpretations and helped to ensure internal validity (Yin, 1989).

A follow-up meeting was held with the main contact within each case to validate interpretation of findings, either face-to-face or by telephone. These meetings sought to validate interpretations and emerging conclusions (Eisenhardt, 1989) and further enquires were made about recent developments and areas of ambiguity. 
INSERT TABLE 1 HERE

\section{Contextual analysis}

Table 1 compares some important contextual characteristics across the three cases and Table 2 provides a brief background description of each case. The focal companies were suppliers to assemblers, or first-tier suppliers. The projects in each case study shared several features but also differed in some respects, for instance, in relation to the extent of product modularity and innovation: the Asian car development project involved radical innovation in the form of the application of a material that had not previously been used in high volume car production. The other two cases concerned more incremental developments.

Moreover, the Asian car development project concerned the development of a car (an end product), although the focal company was an engineering supplier, with a wide-spanning project management role. The fuel tank and the base station projects focused on the development of components and the wider end product perspective was accounted for by end customer interviews.

INSERT TABLE 2 HERE

\section{Analysis of intervention and delegation in supplier selection and communication}

The inter-case analysis reports on patterns of responses across the three cases. The case study design enabled analysis of the intervention and delegation strategies employed by both focal companies and focal company customers. In fact, respondents often divulged how intervention and delegation were used by other companies within their supply network rather 
than themselves. The in-depth case studies therefore illustrated multi-actor strategies within the supply networks.

The findings suggested that companies generally felt a strong need to involve key 'partnership' suppliers early and extensively in their NPD projects. However, there was much variation in the extent to which companies actively sought to involve sub-suppliers during the NPD process and the strategies they employed to seek wider supply network involvement. The following sub-sections report on the manifestations of intervention and delegation strategies identified in supplier selection and communication during the NPD projects.

\subsection{Supplier selection}

Intervention in supplier selection

All three cases showed evidence of extensive intervention in the supplier selection process and it was usually manifested in either specification of sub-suppliers or specification of components that would strongly narrow the field of which sub-suppliers to use. In other words, whereas some companies found it necessary to name sub-suppliers they insisted their direct suppliers use, other companies merely ensured that sub-components complied with their particular specifications. For example, in the base station and the Asian car projects the focal companies both sought to exert their influence on sub-supplier selection through component specification i.e. by virtue of the design by producing very narrow part specifications: 
There is a fairly strong logic that says the person who holds the pencil actually holds the supplier selection as well because the person who does the design work can actually dictate who can make that part. So we ensured that where we found it important to use a particular supplier or that supplier's component, the best design was drawn up using that component.... So it was probably a little bit sneaky to do it that way but rather than impose our will upon them we took the view that the same result would be achieved by designing the vehicle around those standard parts.... We didn't specify those indirect suppliers, we specified which components had to be used and because they had a very limited tooling and development budget they were hamstrung - they could not then justify going and copying that part at another supplier. AutoEngineer

In the fuel tank project J-Car managed part of the indirect supplier selection or specification by using one supplier (S1) as a sourcing agent to Japanese suppliers. The presence of S1 helped the fuel tank supplier to access remote suppliers, whilst also leveraging J-Car's power. A flipside of the intervention strategy in supplier selection was that it resulted in suppliers having their hands tied by their customer's intervention. This became apparent as interviews progressed upstream in the supply networks. For example, S2 admitted that they would have deliberately avoided one of these suppliers if they had had the choice: They are a pain in the neck supplier for me. But basically I have no choice because J-Car has nominated [them].

The fuel tank case demonstrated most clearly the significant implications for suppliers of an interventionist strategy. EuroPart had to cope with extensive intervention by J-Car, who negotiated prices directly with EuroPart's two key suppliers. The relationships amongst EuroPart's main suppliers and its customer J-Car were thus characterized by a system of enforced cost transparency, which J-Car perceived as an advantage, but which constrained 
EuroPart's ability to make what it perceived as a viable profit. Although as one of its respondent stated, if any problems occurred they could turn around and say 'You nominated them'.

A similar pattern was observed in the base station case where the focal company purchased materials directly with one of its sub-suppliers, leaving the supplier with little ability to determine cost and margin levels within its key supplier relationships. Moreover, in conjunction with its customer, the focal company sought to drive sub-suppliers targets to ensure the overall project cost, quality and delivery targets be achieved; these manifestations of intervention strategies were most prominent in the base station case.

Most of the examples of intervention in sub-supplier selection stemmed from final product assemblers rather than the focal companies (suppliers). However, in both the base station project and the Asian car project the focal companies consulted their customers about their assessment of the companies' existing and potential suppliers. The focal companies' customers trusted their suppliers to manage the project on their behalf and did not feel the urge to dictate supplier selection, instead relying on debate and mutual compromise.

\section{Delegation in supplier selection}

Examples of explicit delegation of supplier selection decisions were limited. However when companies made little attempt to manage NPD projects beyond the direct supplier relationships, they tended to perceive this as effectively delegating their requirements to their supply network. Many companies stated that they barely had the resources to manage their 
direct supplier relationships so any attempts to manage beyond these would be utopia. They relied on direct suppliers to manage the process on their behalf, yet they did not appear to have issued any explicit preferences or guidelines for suppliers.

The only exemption was the base station case where TelePart issued parts approval lists with names of suppliers that had demonstrated credibility through past performance and where mutual understanding of needs and requirements had evolved; suppliers were expected to comply fully with the requirements set out on the parts approval list. One of the supplier interviews in the TelePart case showed the difficulty of diverting from the parts approval list:

We've offered alternative manufacturers for the approval process. So far we have not succeeded in introducing [other suppliers]. [Our suppliers] are specified by TelePart-some components are specified through TM as in the electronic devices.... There's been a lot of negotiation between TelePart and TM to get this [approved parts] list together. If there's any deviation from that parts list then it would need to go back through the re-approval process, which costs thousands of pounds and time of the engineers. So once we 've produced this product and it's been approved by TelePart and TM with the range of components then that's set in stone and we can't deviate from that particular range of components. There's a fixed number of alternative manufacturers that TelePart and TM would accept.

Issuing parts approval lists exemplified explicit delegation of supplier selection responsibility. Apart from this practice, however, there was limited evidence of explicit delegation in the supplier selection process. Suppliers were either left to their own devices in their choice of sub-suppliers or delegation took the form of allowing suppliers flexibility to choose their own suppliers provided these complied with approved parts lists. Where 
respondents stated that 'we leave that to suppliers', it was effectively a delegation of decisions to direct suppliers, although the delegation was implicit and informal. In the base station case and, especially, the fuel tank case the extensive intervention in supplier selection seemed to preclude delegated decisions.

\subsection{Communication}

Intervention in communication

Across the cases there were attempts to communicate and share knowledge directly with subsuppliers. This was most evident in the case of the fuel tank development project where J-Car communicated, for example, design changes, terms and conditions, and cost/margin information directly to a group of sub-suppliers. J-Car thereby chose to circumvent EuroPart in its communication with its own suppliers, because it viewed certain components as being so critical, from a commercial and safety point of view, that it needed to take charge of communication with sub-suppliers. Direct intervention was frequently described as a resource demanding strategy, but the fact that automotive fuel tanks present a potential hazard to vehicle manufacturers was a critical factor that provided a strong incentive for the vehicle manufacturer to engage in direct intervention. The relationship between EuroPart and the fuel pump supplier (S2) was also restrained with regard to openness of communication. S2 submitted that design information relating to its component and underlying technology was withheld from EuroPart, because it was not seen as "part of the process" and because of fears that EuroPart might use the information to develop its own fuel pump. 
Intervention was more limited in the other two cases. In the Asian car project AutoEngineer brought together two suppliers to jointly engage in knowledge sharing and problem solving processes. In the base station project there were similar examples of the focal company, TelePart, bringing together suppliers to resolve delivery problems, which TelePart was unable to resolve at a dyadic level.

\section{Delegation in communication}

Although the cases illustrated extensive direct communication between companies and their indirect suppliers through intervention, this did not completely preclude delegation of communication. In the Asian car project AutoEngineer delegated communication responsibility to its suppliers by actively encouraging these to ensure clarity of project goals within their supply network. Furthermore, AutoEngineer encouraged communication between two prototype suppliers, facilitating knowledge sharing and joint problem-solving. In the base station project there were similar examples of suppliers at the same tier being encouraged by their customer to communicate with each other, and joining forces in trying to resolve delivery problems, which TelePart was unable to resolve through involving only direct suppliers.

Elsewhere, delegation often took the form of 'delegation by default' with companies expecting suppliers to share information with their own suppliers, but apparently without issuing any explicit or formal instructions to do so. In such cases, the standard response was that 'this was left to suppliers'. Table 3 provides an overview of the findings on supply network intervention and delegation in supplier selection and communication during NPD across the three cases. 


\section{Discussions and conclusions}

In summary, the three case studies show that companies do attempt to involve not only direct suppliers but also key sub-suppliers within the wider supply network. Some companies involved indirect suppliers much more extensively than others, however, and there were evidently both positive and negative implications of engaging in the wider supply network.

The fuel tank case exhibited the most extensive supply network intervention, predominantly by J-Car. This company intervened in the key sub-supplier selection process, and in communication of critical design changes and commercial negotiations with key sub-

suppliers; J-Car thus exerted strong power and influence over its entire fuel tank supply network, leaving EuroPart as the (supposedly) full systems supplier of the fuel tank in a very difficult situation. Consider the other automotive case, the Asian car project: here the vehicle assembler relied much more extensively on delegation and employed intervention in a more indirect and subtle manner. However, the base station project resembled the fuel tank project in several ways, notably the use of intervention in sub-supplier selection. The base station case showed how delegation was used in combination with intervention with seemingly good results, causing far less friction amongst supply network actors.

\subsection{Manifestations of supply network intervention and delegation strategies}

The three case studies showed how supply network intervention and delegation strategies were manifested in different ways across supply networks in the context of supplier selection 
and communication processes. This section reflects on the different ways in which the two strategies were conducted across the cases.

\section{Delegation}

The delegation strategy represents one possible way to actively involve and influence indirect suppliers in a company's NPD project, and thereby reach into the capabilities and technologies that exist within the wider supply network. In the case studies the delegation strategy was manifested in three different ways:

1. Issuing parts approval lists. The practice of issuing parts approval lists to direct suppliers constituted an explicit and formalized approach to entrust authority and responsibility to direct suppliers. For example, the telecommunications OEM in the base station case (TM) issued a parts approval list to its direct suppliers in order to ensure that its standards were met throughout the wider supply network; the investment in producing approved parts lists was significant as customers were unwilling to deviate from the lists. Such explicit use of delegation within the supply network was therefore an important means to involve suppliers in the NPD project whilst still maintaining a degree of control.

2. Encouraging communication and problem solving. The practice of encouraging suppliers to share information with their suppliers was another example of an explicit approach to delegation. The use of the term 'encouragement' by many respondents emphasized the voluntary nature of this form of delegation; interviews with those suppliers being encouraged by their customers suggested that they perceived this approach to delegation as motivating (Osterloh and Frey, 2000): as they were 'encouraged' rather than forced it gave them discretion. 
3. 'Leaving it to suppliers'. This approach could be seen as delegating by default: suppliers were expected to manage the involvement of their own suppliers without explicit instructions or encouragement. Such an approach gave the customer little control over the involvement of indirect suppliers in NPD projects. Instead they trusted that suppliers had the competencies to manage their own suppliers, which might work well where suppliers are capable to manage independently (Sako, 1992; Ragatz et al., 1997). The risk was that a company might work hard to ensure the involvement of its direct suppliers both early and closely in the design and development process, but the company might do nothing to ensure the active involvement of the rest of its supply network.

\section{Intervention}

The findings showed intervention to be a common strategy, practiced by several actors to enable the supplier and sub-supplier selection process and communication. Across the cases the intervention strategy was manifested in four different ways:

1. Selecting/specifying sub-suppliers. In the fuel tank case there was extensive specification of sub-suppliers by the powerful Japanese vehicle assembler J-Car. This strategy assured J-Car that critical fuel tank components were sourced from trusted sources. Intervention in sub-supplier specifications during NPD projects seems to fit the high level of supply chain engagement of Japanese automakers, and helps to maintain cost transparency as also established by Sako (2004) and Cousins (2001). A more moderate version of this approach was observed in the Asian car and base station cases where the components supplied by sub-suppliers were specified rather than the actual suppliers. This was closely related to the use of parts approval lists, as discussed under delegation strategies, but it was not so much a list as a very narrow choice based where suppliers were technically 
free to choose any sub-supplier they wanted provided that component specifications were met. As AutoEngineer revealed in the Asian car case, this was done to make it seem less dictatorial than specifying the actual supplier although, in reality, the supplier's freedom was limited.

2. Negotiating/purchasing from sub-suppliers. The fuel tank and base station cases illustrated how manufacturers not only selected indirect suppliers but also negotiated directly with these. In the fuel tank case, this method of intervention gave J-Car full visibility of the costs and margins of sub-suppliers of high value components, so reinforced cost transparency within the supply network (Lamming et al., 2004). Such direct purchasing methods (Brown et al., 2005) have received relatively little attention in the literature. The case studies in the present study indicated that this provided much cost transparency although, as discussed later, not necessarily in the interest of those suppliers being circumvented during the negotiation process.

3. Communicating design changes and commercial information to sub-suppliers. The fuel tank case stood out by providing yet another example of intervention: communication of design change information directly from J-Car to EuroPart's suppliers. This was done to ensure that key sub-suppliers were made directly aware of design changes and thereby avoiding distortion of information and, ultimately, project delays. Furthermore, commercial information, relating to cost and terms \& conditions, were communicated right across several tiers within this supply network. Although direct exchange of information across tiers is a core principle of SCM (Lambert and Cooper, 2000), there is little research exploring exchange of design information through the intervention method.

4. Uniting sub-suppliers for knowledge sharing \& problem solving. The Asian car and the base station projects both showed how companies had chosen to bring together a group of suppliers at the same tier in order to resolve technical problems. They reasoned that none 
of the suppliers could solve the problems on their own; they would have been unlikely to collaborate without the focal companies' intervention. In a similar vein to Dyer and Nobeoka's (2000) analysis of Toyota's knowledge-sharing network, these two cases showed how manufacturers can facilitate multidirectional knowledge flows among suppliers.

Figure 2 illustrates the different manifestations, or examples, of the intervention and delegation strategies observed across the cases. Other strategies may exist but were not identified in this study.

\section{INSERT FIGURE 2 HERE}

7.2. Implications of supply network intervention and delegation strategies for supplier selection and communication

The cases pointed to several implications of delegation and intervention. It was evident that some of these were predominantly positive, whereas others were negative, depending on which supply network actor perspective one adopts. In general, intervention was regarded as a positive, or simply necessary, strategy by assemblers or OEMs, whereas suppliers often viewed intervention as a negative intrusion in their business. In this section we outline the different sides of the two strategies.

\section{Empowering suppliers through delegation}

Organizational behaviour theory suggests that delegation of decisions within organizations helps to motivate and empower employees and foster local learning and use of local 
knowledge (Osterloh and Frey, 2000; Conger and Kanungo, 1988; Foss et al., 2006). Our case focused on NPD within customer-supplier relationships and networks and there were indications that some positive effects of delegation also applied in an inter-organizational context. For example, the Asian car and base station projects exemplified how companies encouraged their suppliers to communicate with other suppliers. Both of these projects concerned products with a high degree of modularity, so the delegation approach was logical (Sanchez and Mahoney, 1996; Baldwin and Clark, 1997). The implicit approach to delegation - 'leaving it to suppliers' - which was the more common approach in the case studies, provided little obvious guidance to suppliers as to how they were supposed to manage their own supplier relationships during NPD projects; although it provided a framework for task partitioning and autonomous working within supply networks (Von Hippel, 1990) it was questionable if this approach was as effective in empowering suppliers as the more explicit approach.

\section{Controlling supply networks through intervention and explicit delegation}

Although explicit delegation of decisions concerning supplier selection and communication to direct suppliers appeared to have positive implications for empowerment and motivation, there were no indications in this study that implicit delegation, 'leaving it to suppliers', had the same effects. There was certainly a risk that this approach relied on a wishful hope or blind trust (Williamson, 1993), that direct suppliers would act on behalf of customers. If companies choose to involve suppliers in NPD they arguably need to take appropriate measures to control the NPD process within a wider supply network context; explicit delegation provides one way to achieve such control but intervention provides another, perhaps more reassuring, method to managers. In fact, many respondents explained that where components were critical, particularly from a safety perspective, they felt inclined to 
intervene directly in indirect supplier selection and communication to ensure compliance from suppliers (Johnsen and Ford, 2007). Product liability implies that companies can ill afford to take chances with the NPD process.

Moreover, companies perceive that they can control cost better by exerting authority through intervention within the supply network. Controlling the supply network through such methods is entirely consistent with SCM, which assumes that companies possess the power to, and may benefit from, delegating and intervening across dyadic supplier relationships (Lamming, 1996). The cases exemplified how companies apparently obtained full visibility of costs within the supply network by communicating and sometimes negotiating directly with indirect suppliers. The potential cost implications from such intervention may therefore be significant. From a supplier perspective, however, the cases demonstrated clearly how they felt constrained in their own supplier selection and communication, and we may question if intervention results in the desired effects from an overall supply network perspective.

\section{'Tying the supplier's hands': the flipside of intervention}

The case studies revealed how one company's attempts to intervene within the wider supply network presented significant problems for those suppliers effectively 'caught in the middle'. In the cases in which network intervention strategies were applied extensively, especially the fuel tank project, some suppliers had to cope with customer interventions in their own supply base. Intervention significantly affected the ability of suppliers to control their own supplier selection process and communication. 
The notion of 'tying the manager's hands' (Root, 1989; Foss et al., 2006) expresses well the situation of suppliers having to cope with customer intervention, so in this case we can express the same situation as 'tying the supplier's hands'. Intervention may give the customer (the intervenor) more control over which suppliers are involved in NPD projects, communication with these, and cost control. However, the risk is that forceful and opportunistic intervention results in sub-optimization (Williamson, 1996) within the supply network and is damaging to overall value creation: although it gives the intervenor a sense of increased control it potentially harms the customer-supplier relationship dynamics critical to successful supplier involvement in NPD. This view has been suggested both in industrial network theory (Håkansson, 1987; Ford et al., 2003) and the more mainstream supplier involvement in NPD literature (Ragatz et al., 1997; LaBahn and Krapfel, 2000; Song and Benedetto, 2007). In particular, several studies (Bstiler, 2006; Cousins and Crone, 2003; Ragatz et al., ibid) emphasized the importance of buyer-supplier trust and commitment as pre-requisites for successful supplier involvement. Supply network intervention can easily ruin an otherwise constructive relationship atmosphere and may thereby impact negatively on innovation.

Intervention in component specification rather than supplier specification potentially presents a way to avoid the negative consequences of the intervention strategy. Combined with a more consultative approach, as applied by for example TM and TelePart in the base station case, a moderate approach to intervention could help to prevent friction amongst supply network actors.

\section{Conceptual and managerial implications}


This paper has proposed two strategies that companies can employ to access indirect suppliers: supply network delegation and supply network intervention. These two concepts have received some attention in previous research (Lamming, 1996; Johnsen and Ford, 2005, 2007). This paper has contributed to a better definition and conceptualization of these two strategies, by building on the traditional NPD, organizational behaviour and economics literatures. Where Johnsen and Ford (2007) focused on situations of delegation and intervention deployment, this paper has added further conceptualization and explored both manifestations and multi-actor implications of delegation and intervention in supply networks.

The findings have shown the different manifestations of the two strategies, when applied as part of supplier involvement in NPD. Delegation may be manifested through issuing parts lists, encouraging communication and problem solving, and an implicit 'leaving it to suppliers' approach. Intervention may be manifested through specifying sub-suppliers, either by nominating suppliers or specifying components, purchasing from and negotiating directly with sub-suppliers, communicating design changes and commercial information directly to sub-suppliers, and uniting sub-suppliers for knowledge sharing and problem solving.

The findings have also elucidated positive and negative implications of delegation and intervention strategies. This seems to be dependent on the actor perspective i.e. from a downstream manufacturer perspective there is a perceived need to control the NPD process across several supply network tiers through direct intervention in supplier selection and communication, but from an upstream perspective these actions are likely to be restricting for suppliers and lead to sub-optimization (Williamson, 1996). In comparison with the 
mainstream supplier involvement literature, which remains largely dyadic (e.g. Wasti and Liker, 1997; Petersen et al., 2005), the paper has contributed to a better understanding of how to involve not only direct suppliers, but also indirect (sub-) suppliers in NPD. The paper proposes that the concept of 'tying the manager's hands' (Foss et al., 2006) may equally apply in an inter-organizational supply network context, expressed as 'tying the supplier's hands'. Below, two managerial implications are briefly outlined.

\section{Reach out to entire supply networks}

The importance of involving not only direct suppliers in NPD projects, but also the wider supply network, has been emphasized in this paper. It is insufficient to focus purely on the involvement of direct suppliers when the performance of a company's direct suppliers themselves is heavily dependent on the wider supply network; this is especially true when seeking to develop radical innovations. When companies face conditions of technological uncertainty (Ragatz et al., 2002; Song and Benedetto, 2007), managers need to involve the wider supply network rather than purely look to direct suppliers. Indeed, such conditions may require connecting with new suppliers outside existing networks that are not within the company's usual field of vision (Birkinshaw et al., 2007).

\section{Deploy intervention and/or delegation - with care}

This paper has proposed and conceptualized two strategies that companies can employ to seek to involve their wider supply network: supply network delegation and intervention. Delegation fits modular products well as they allow a greater extent of task partitioning. Managers need to be aware that there are good ways and bad ways to deploy these. The delegation strategy should mean more than simply 'leaving it to suppliers'. Even though companies would like to trust their core strategic suppliers to make decisions on their behalf, 
it is necessary to ensure that customer expectations and preferences are transparent. A delegation strategy in which companies clearly and explicitly influence supplier selection and communication within a small number of strategic suppliers, and trust these to manage their own supplier relationships, is more likely to yield the desired outcomes. This could be done, for example, by issuing parts approval lists and encouraging communication and problem solving amongst suppliers. Managers may benefit from complementing supply network delegation with direct intervention in the wider supply network, for example to influence the choice of key sub-suppliers. However, managers should take care to do so through component rather than supplier specification, and avoid tying their suppliers' hands by forcing them to work with particular suppliers.

\section{Limitations and future avenues of research}

The paper is based on a limited number of in-depth case studies conducted across two industries. None of the three cases stood out as being unique in any way, although each individual case featured particular themes. The external validity provided by three cases constituted a first step towards replication and thus testing of the findings in different situations. However, caution is required in any generalizations to other industries with different technological characteristics.

Further research is required in a wider number of research contexts to analyze the outcomes of supply network strategies. Johnsen and Ford (2007) focused on such issues, suggesting various contextual factors that appear to be important in understanding patterns of delegation and intervention, but this study did not set out to test these links. Moreover, the link between NPD characterized by different degrees of innovation and the need for supply network involvement warrants further research. Future research might also consider how suppliers 
participate if different stages of the NPD process and the relevance of delegation and intervention strategies across these stages. Finally, longitudinal or large scale survey research assessing the performance outcomes of supply network delegation and intervention would help to elucidate in which contexts the different forms of intervention and delegation strategies predict superior NPD performance.

\section{References}

Baker, G., Gibbons, R. and Murphy, K.J. (1999), "Informal authority in organizations", Journal of Law, Economics, and Organizations, Vol. 15 No. 1, pp. 56-73.

Baldwin, C.Y. and Clark, K.B. (1997), "Managing in the age of modularity", Harvard Business Review, Vol. 75 No. 5, pp. 84-93.

Birkinshaw, J., Bessant, J. and Delbridge, R. (2007), "Finding, forming, and performing: creating networks for discontinuous innovation", California Management Review, Vol. 49, pp. 67-83.

Brockner, J., Tyler, T.R. and Cooper-Schneider, R. (1992), "The influence of prior commitment to an institution on reactions to perceived unfairness: the higher they are, the harder they fall”, Administrative Science Quarterly, Vol. 37, pp. 241-61.

Brown, J.R., Dant, R.P., Ingene, C.A., and Kaufmann, P.J. (2005), "Supply chain management and the evolution of the 'big middle"”, Journal of Retailing, Vol. 81 No. 2, pp. 97-105.

Clark, K.B. and Fujimoto, T. (1991), "NPD Performance: Strategy, Organization, and Management in the World Auto Industry”, Cambridge: Harvard Business School Press. 
Conger, J. and Kanungo, R. (1988), “The empowerment process: integrating theory and practice", Academy of Management Review, Vol. 13 No. 3, pp. 471-482.

Cousins, P.D. (2001), “It's only a matter of confidence!” International Journal of Operations and Production Management, Vol. 21 No. 9, pp. 1160-1179.

Cousins, P.D. and Crone, M.J. (2003), "Strategic models for the development of obligationbased inter-firm relationships, International Journal of Operations and Production Management, Vol. 23 No. 12, pp. 1447-1474.

Dyer, J. and Nobeoka, K. (2000), "Creating and managing a high performance, knowledge sharing network: the Toyota case", Strategic Management Journal, Vol. 21, pp. 345367.

Eisenhardt, K.M. (1989), "Building theories from case study research", Academy of Management Review, Vol. 14 No. 4, pp. 532-550.

Fliess, S. and Becker, U. (2006), "Supplier integration - controlling of co-development processes", Industrial Marketing Management, Vol. 35 No. 1, pp. 28-44.

Ford, D., Gadde, L.E., Håkansson, H., and Snehota, I. (2003), “Managing Business Relationships", Wiley, $2^{\text {nd }}$ ed., Chichester, England.

Foss, K., Foss, N.J., and Vazquez, X.H. (2006), “Tying the manager's hands: constraining opportunistic managerial intervention", Cambridge Journal of Economics, Vol. 30, pp. 797-818.

Håkansson, H. (ed.) (1987), “Industrial Technological Development: A Network Approach”, Croom Helm, London.

Hartley, J.L., Zirger, B.J., and Kamath, R.R. (1997), "Managing the buyer-supplier interface for on-time performance in product development", Journal of Operations Management, Vol. 15, pp. 57-70. 
Hines, P. (1996), "Network Sourcing", in Lamming, R.C. and Cox, A. (eds.) A Strategic Procurement Management in the 1990s: Concepts and Cases, Boston, Earlsgate Press, UK.

Imai, K., Nonaka, I. and Takeuchi, H. (1985), "Managing the new NPD process: how Japanese companies learn and unlearn", in K. Clark, R. Hayes and C. Lorentz (eds) The Uneasy Alliance: Managing the Productivity-Technology Dilemma, Harvard Business School Press: Cambridge, MA, pp. 337-381.

Johnsen, T.E. and Ford, D. (2005), “At the Receiving End of Customer Supply Network Intervention", Journal of Purchasing and Supply Management, Vol. 11, No. 4, pp. 183-192.

Johnsen, T.E. and Ford, D. (2007), "Customer approaches to NPD with suppliers", Industrial Marketing Management, Vol. 36, p. 300-308.

Karlsson, C., Nellore, R. and Söderquist, K. (1998), "Black box engineering: redefining the role of product specifications", Journal of Product Innovation Management, Vol. 15, pp. 534-549.

LaBahn, D.W and Krapfel, R. (2000), "Early supplier involvement in customer new product development: a contingency model of component supplier intentions”, Journal of Business Research, Vol. 47 No. 3, pp. 173-190.

Lambert, D.M. and Cooper, M.C. (2000), "Issues in supply chain management", Industrial Marketing Management, Vol. 29, pp. 65-83.

Lamming, R.C. (1996), "Squaring lean supply with supply chain management", International Journal of Operations and Production Management, Vol. 16 No. 2, pp. 183-196.

Lamming, R.C., Caldwell, N.D. and D. Harrison (2004), "Developing the concept of transparency for use in supply relationships”, British Journal of Management, Vol. 15, pp. 291-302. 
Lau, A.K.W. and Yam, R.C.M. (2005), “A case study of product modularization on supply chain design and coordination in Hong Kong and China", Journal of Manufacturing Technology and Management, Vol. 16 No. 4, pp. 432-446.

Littler, D., Leverick, F. and Bruce, M. (1995), "Factors affecting the process of collaborative product development: a study of UK manufacturers of information and communications technology products", Journal of Product Innovation Management, Vol. 12 No. 1, pp. 1-18.

Miles, M. and Huberman, M.A. (1984), “Qualitative Data Analysis: a Sourcebook of New Methods", Newbury Parl and London: Sage.

Mowday, R.T., Steers, R.M. and Porter, L.W. (1982), “Employee-Organization Linkages: The Psychology of Commitment, Absenteeism and Turnover", New York, Academic Press.

Mullins, L.J. (2005), “Management and Organizational Behaviour". 7th Ed. Harlow, England: Prentice Hall.

Osterloh, M. and Frey, B.S. (2000), "Motivation, knowledge transfer and organizational form”, Organization Science, Vol. 11 No. 5, pp. 538-550.

Petersen, K., Handfield, R. and Ragatz, G. (2003), “A model of supplier integration into new product development”, Journal of Product Innovation Management, Vol. 20 No. 4, pp. 284-299.

Petersen, K.J., Handfield, R.B. and Ragatz, G.L. (2005), "Supplier integration into new product development: coordinating product, process and supply chain design", Journal of Operations Management, Vol. 23 No. 3-4, pp. 371-388.

Ragatz, G.L., Handfield, R.B. and Scannell, T.V. (1997), "Success factors for integrating suppliers into product development”. Journal of Product Innovation Management, Vol. 14 No. 3, pp. 190-202. 
Ragatz, G.L., Handfield, R.B. and Petersen, K.J. (2002), "Benefits associated with supplier integration into new product development under conditions of technological uncertainty", Journal of Business Research, Vol. 55, pp. 389-400.

Ramsay, J. (1998), "Problems with empiricism and the philosophy of science: Implications for purchasing research”, European Journal of Purchasing and Supply, Vol. 4 No. 2/3, pp. 163-173.

Robson, C. (1997), “Real World Research”, Blackwell, Oxford, UK.

Root, H. (1989), "Tying the king's hands: royal fiscal policy during the old regime", Rationality and Society, Vol. 1 No. 2, pp. 240-259.

Sako, M. (1992), Prices, Quality and Trust: Inter-Firm Relations in Britain and Japan, Cambridge University Press, Cambridge, UK.

Sako, M. (2004), "Supplier development at Honda, Nissan and Toyota: comparative case studies of organizational capability enhancement", Industrial and Corporate Change, Vol. 13 No. 2, pp. 281-308.

Sanchez, R. and Mahoney, J.T. (1996), "Modularity, flexibility, and knowledge management in product and organization design”, Strategic Management Journal, Vol. 17 Winter Special Issue, pp. 63-76.

Simon, H.A. (1951), "A formal theory of the employment relationship", in Models of Bounded Rationality, Cambridge, MIT Press, 1982.

Simon, H.A. (1962), "The architecture of complexity", Proceedings of the American Philosophical Society, Vol. 106, pp. 467-482.

Song, M. and Benedetto, A.D. (2008), "Supplier's involvement and success of radical new product development in new ventures", Journal of Operations Management, Vol. 26 No. 1, pp. 1-22. 
Staudenmayer, N., Tripsas, M. and Tucci, C.L. (2005), "Interfirm modularity and its implications for NPD”, Journal of Product Innovation Management, Vol. 22, pp. 303321.

Thomas, K.W. and Velthouse, B.A. (1990), "Cognitive elements of empowerment: an interpretive model and intrinsic task motivation", Academy of Management Review, Vol. 15 No. 4, pp. 666-681.

Ullrich, K. (1995), "The role of product architecture in the manufacturing firm", Research Policy, Vol. 24, pp. 419-440.

Van Echtelt, F.E.A., Wynstra, F., Van Weele, A.J. and Duyesters, G. (2008), "Managing supplier involvement in NPD: a multiple-case study", Journal of Product Innovation Management, Vol. 25, pp. 180-201.

Von Hippel, E. (1990), “Task partitioning: an innovation process variable”, Research Policy, Vol. 19 Summer, pp. 407-418.

Voss, C., Tsikriktsis, N., and Frohlich, M. (2002), "Case research in operations management", International Journal of Operations and Production Management, Vol. 22, pp. 195-219.

Wasti S.N. and Liker J.K. (1997), "Risky business or competitive power? Supplier involvement in Japanese product design", Journal of Product Innovation Management, Vol. 14, pp. 337-355.

Williamson, O.E. (1970), “Corporate control and business behavior", Englewood Cliffs: Prentice-Hall.

Williamson, O.E. (1993), “Calculativeness, trust and economic organization”, Journal of Law and Economics, Vol. 36 No. 1, pp. 453-486.

Williamson, O.E. (1996), "The Mechanisms of Governance”, Oxford University Press, London. 
Wynstra, F. and ten Pierick, E. (2000), "Managing supplier involvement in new product development: a portfolio approach", European Journal of Purchasing and Supply Management, Vol. 6, pp. 49-57.

Yin, R.K. (1989), “Case Study Research: Design and Methods”, 2nd edn., Newbury Park and London, Sage.

\section{Appendix A - Interview Protocol}

Most questions were open-ended and the interviewer provided interviewees the opportunity to provide illustrative examples. Nature of questions varied depending on whether respondents represented focal company, suppliers or customers. The following represents an abbreviated generic version of the actual instruments used.

\section{Respondent, company and project context:}

- $\quad$ Respondent position and responsibility

- Size of organization in terms of employees and turnover

- Major products and core technologies

- Degree of product modularity/integral architecture

- Current stage or completion date of NPD project

- Arrangements for sharing of development costs

Extent of innovation and performance:

- $\quad$ Product and process technologies developed for new product

- Extent of innovation in NPD project

- Target and actual development cost and time

- $\quad$ Target and actual product cost

- $\quad$ Patents and awards received

- $\quad$ Learning experience

Mapping of supply network (this part of interviews involved network mapping):

- Main suppliers involved in development and their suppliers

- Main distributors and customers involved in development

- Any other companies involved, including competitors, complementary manufacturers in other industries, research institutions, consultants

\section{Supplier involvement processes:}

- $\quad$ Process of supplier identification and selection

- Supplier selection criteria and timing of involvement

- Ability to choose own suppliers e.g. influence of other actors

- Attempts to manage supplier selection in wider supply network e.g. through delegation and intervention

- Process and extent of communication e.g. in relation to design ideas, concepts, policies, procedures and performance

- $\quad$ Alignment of technology plans

- Attempts to communicate and share information in wider supply network e.g. through delegation and intervention 
Figure 1. Simplified Supply Network Maps

Fuel Tank Supply Network Map

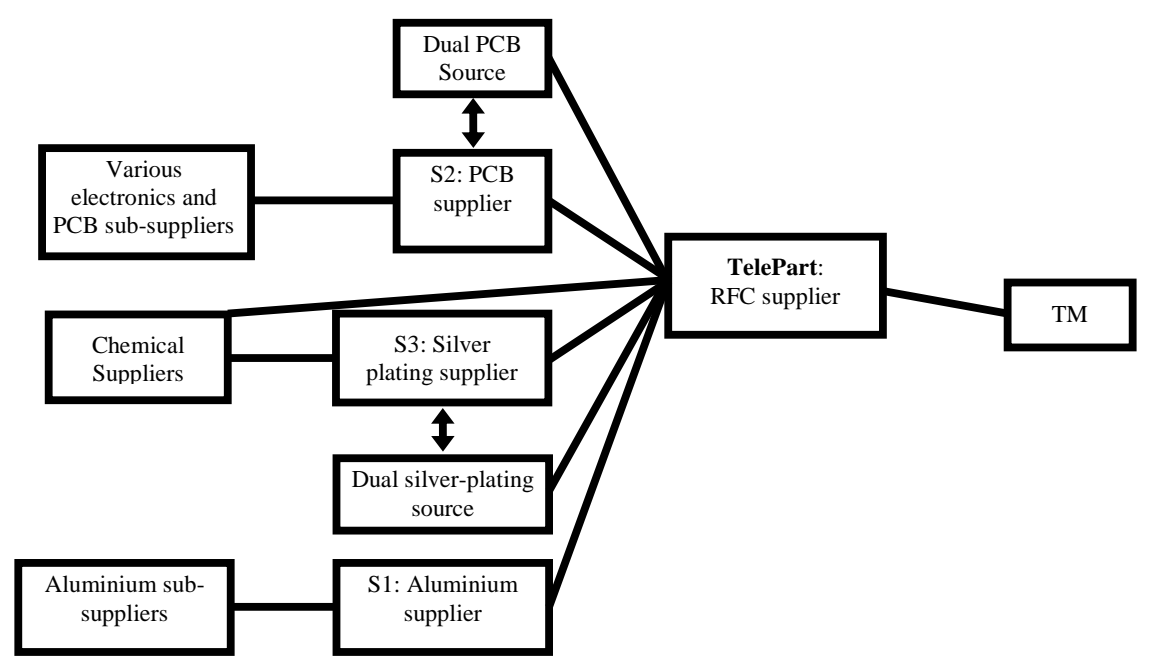

Base Station Supply Network Map

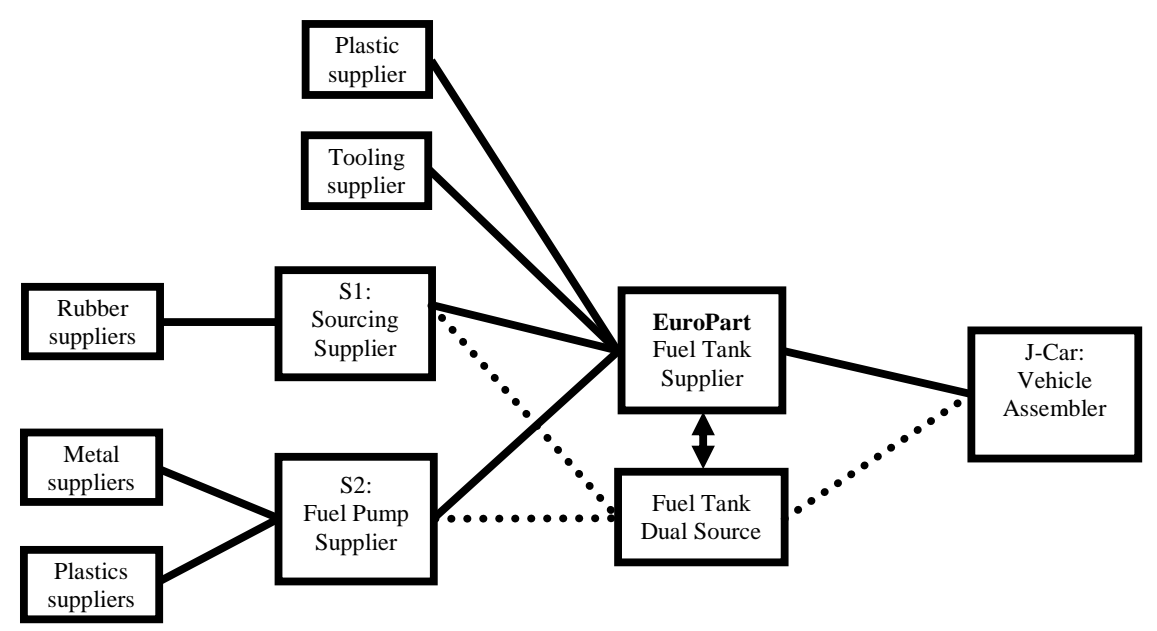

Asian Vehicle Supply Network Map

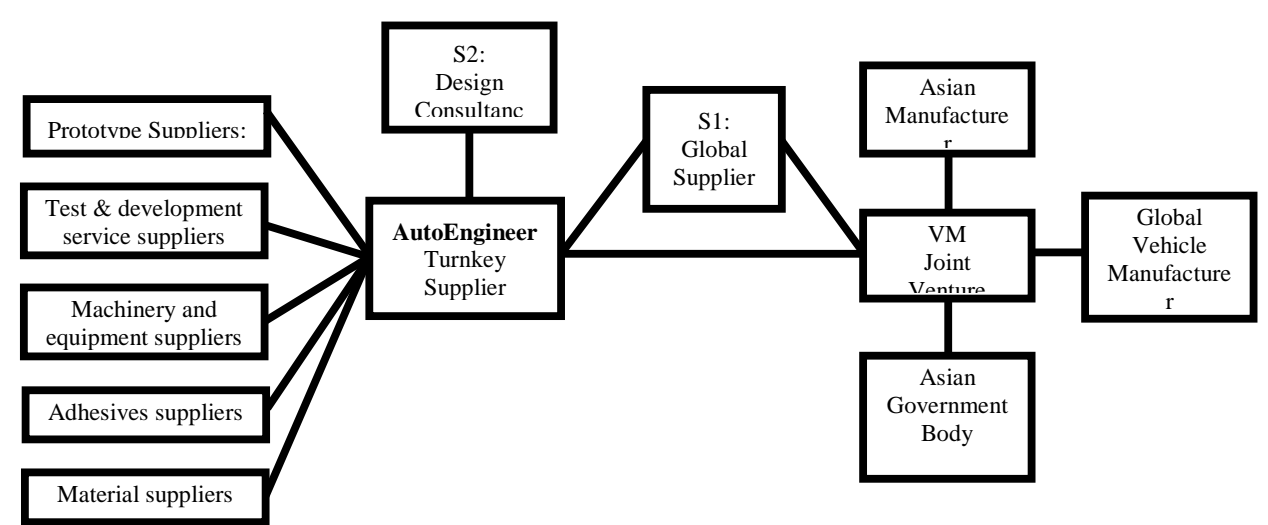


Figure 2. Manifestations of Supply Network Delegation and Intervention

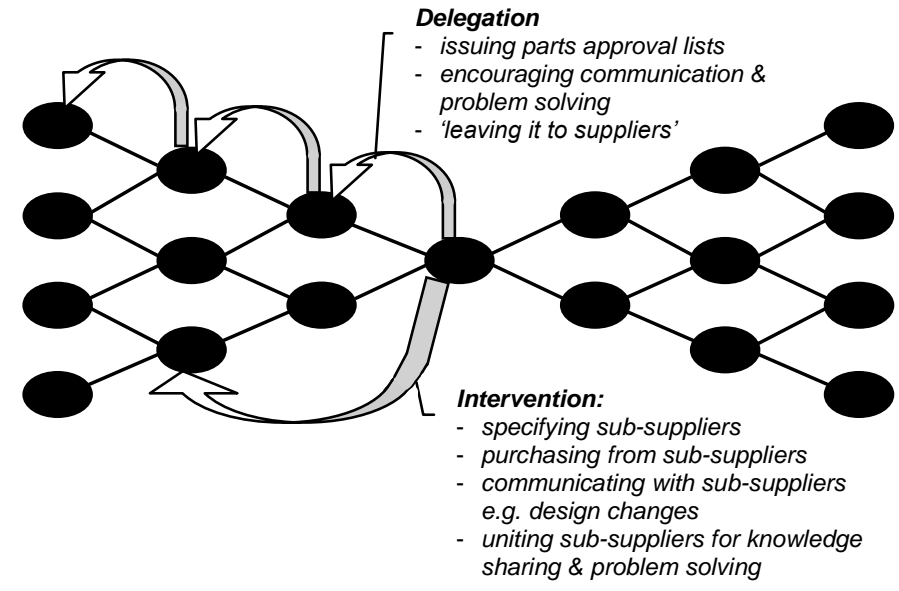


Table 1. Case Study Characteristics

\begin{tabular}{|c|c|c|c|}
\hline & Fuel Tank Project & Asian Car Project & Base Station Project \\
\hline Interviews & $\begin{array}{l}12 \text { interviews: } 7 \text { focal firm, } 4 \\
\text { suppliers, } 1 \text { customer }\end{array}$ & $\begin{array}{l}10 \text { interviews: } 7 \text { focal firm, } 2 \\
\text { suppliers and } 1 \text { customer }\end{array}$ & $\begin{array}{l}12 \text { interviews: } 8 \text { focal firm, } 3 \\
\text { suppliers and } 1 \text { customer }\end{array}$ \\
\hline NPD project & $\begin{array}{l}\text { Automotive fuel tank - safety } \\
\text { criticality driven }\end{array}$ & $\begin{array}{l}\text { Car for Asian markets - cost } \\
\text { and safety driven }\end{array}$ & $\begin{array}{l}\text { Radio frequency (RF) } \\
\text { component for base stations - } \\
\text { cost driven }\end{array}$ \\
\hline $\begin{array}{l}\text { Project stage } \\
\text { at data } \\
\text { collection }\end{array}$ & Recent launch/ramp-up & Ramp-up & Final prototyping \\
\hline $\begin{array}{l}\text { Focal } \\
\text { company (FC) }\end{array}$ & $\begin{array}{l}1^{\text {st }} \text { tier automotive parts } \\
\text { supplier: 'EuroPart' }\end{array}$ & $\begin{array}{l}1^{\text {st }} \text { tier automotive engineering } \\
\text { supplier with full Turnkey } \\
\text { project responsibility: } \\
\text { 'AutoEngineer' }\end{array}$ & $\begin{array}{l}1^{\text {st }} \text { tier telecoms network } \\
\text { supplier: 'TelePart' }\end{array}$ \\
\hline $\begin{array}{l}\text { Product } \\
\text { architecture }\end{array}$ & Modular & Modular & Modular \\
\hline $\begin{array}{l}\text { Underlying } \\
\text { technology } \\
\text { and level of } \\
\text { innovation }\end{array}$ & $\begin{array}{l}\text { New application of material } \\
\text { technology: incremental NPD }\end{array}$ & $\begin{array}{l}\text { New body-in-white material } \\
\text { applied first time in high- } \\
\text { volume vehicle production } \\
\text { enabling a process innovation. } \\
\text { Patents pending - radical } \\
\text { innovation }\end{array}$ & $\begin{array}{l}\text { New RF upgrade: incremental } \\
\text { NPD }\end{array}$ \\
\hline Performance & $\begin{array}{l}\text { Target development cost and } \\
\text { time achieved } \\
\text { Frustrating project }\end{array}$ & $\begin{array}{l}\text { Unspecified project delay } \\
\text { Frustrating project }\end{array}$ & $\begin{array}{l}\text { Project delay } 6 \text { months } \\
\text { Target cost not achieved } \\
\text { Management problems }\end{array}$ \\
\hline
\end{tabular}

NB: FC denotes Focal Company in each case 


\section{Table 2. The Three Case Studies}

Fuel Tank Project: This case concerned the development of a fuel tank module for a Japanese vehicle manufacturer. The focal company, 'EuroPart', operated as a $1^{\text {st }}$ tier supplier to the automotive industry, and was a joint venture (JV) between a UK company and a continental European company. The fuel tank project applied a newly developed composite material. EuroPart had only one customer in this project ('J-Car'): a Japanese vehicle manufacturer. J-Car dual sourced its fuel tanks from EuroPart and a long-term Japanese supplier. EuroPart's supply network consisted mainly of plastics suppliers, and suppliers of blow- and injection mouldings, high-pressure die-casts, and tooling. Two indirect suppliers were critical: S1, sourced 'child parts' (sub-components) into European $1^{\text {st }}$ tier suppliers for J-Car. Secondly, S2 was the UK subsidiary for a major Japanese parts supplier (S2 Japan).

Asian Car Project: This case focused on a vehicle development project aiming at high volume sales in East Asia. The focal company, AutoEngineer, had full turnkey responsibility for vehicle design, engineering, plant construction and sourcing in Asia. The project involved the application of a new composite material offering substantial cost and weight advantages. AutoEngineer's customer was a JV between a global vehicle manufacturer ('VM') and an Asian manufacturing plant and a government body. The supply network also included production suppliers and machinery and equipment suppliers. S1, a global $1^{\text {st }}$ tier supplier, originally sub-contracted the design to AutoEngineer later transferring all responsibilities to its Asian branch. S2, a design consultancy based in Asia, was a collaboration between VM and S1 that conducted initial styling concepts and engineering and ultimately full engineering responsibility.

Base Station Equipment Project: This case focused on the development of a new high frequency radio filter component (RFC) for telecommunications base stations. The project involved some new applications but mainly of proven technology. 'TelePart'; the focal company in the case, was a first tier base station supplier, specializing in commercial wireless communication. TelePart was the single source with its customer, a major global telecommunications OEM ('TM'). S1, a medium-sized company specializing in high pressure and precision die-casting, supplied component bodies. S2, a small telecoms contract manufacturer, had less design involvement in the project. S3 was a small internal supplier providing silver-plating. 
Table 3. Supply Network Intervention and Delegation Across Three Cases

\begin{tabular}{|c|c|c|c|}
\hline & Fuel Tank Project & $\begin{array}{c}\text { Asian Car } \\
\text { Project }\end{array}$ & Base Station Project \\
\hline \multirow[t]{2}{*}{$\begin{array}{l}\text { Supplier } \\
\text { selection }\end{array}$} & $\begin{array}{l}\text { Intervention: } \\
\text { - FC's customer nominated } \\
\text { key sub-suppliers and } \\
\text { negotiated directly with FC's } \\
\text { most critical supplier } \\
\text { - In one relationship } \\
\text { specification was managed } \\
\text { through sourcing function }\end{array}$ & $\begin{array}{l}\text { Intervention: } \\
\text { FC specified sub-supplier } \\
\text { parts for safety-critical parts } \\
\text { in consultation with } \\
\text { customer }\end{array}$ & $\begin{array}{l}\text { Intervention: } \\
\text { - Specification of sub- } \\
\text { supplier parts jointly with } \\
\text { FC customer } \\
\text { - FC consulted its customer } \\
\text { re. its assessment of sub- } \\
\text { suppliers } \\
\text { - FC negotiated \& purchased } \\
\text { materials on S4's behalf }\end{array}$ \\
\hline & $\begin{array}{l}\text { Delegation: Mostly } \\
\text { intervention; only delegation } \\
\text { where companies simply left } \\
\text { supplier selection decision to } \\
\text { suppliers }\end{array}$ & $\begin{array}{l}\text { Delegation: Companies left } \\
\text { supplier selection to } \\
\text { suppliers }\end{array}$ & $\begin{array}{l}\text { Delegation: } \\
\text { - FC customer produced } \\
\text { parts approval list to which } \\
\text { suppliers must adhere } \\
\text { - Supplier selection usually } \\
\text { left to suppliers }\end{array}$ \\
\hline \multirow[t]{2}{*}{ Communication } & $\begin{array}{l}\text { Intervention: } \\
\text { FC's customer } \\
\text { communicated design } \\
\text { changes directly with sub- } \\
\text { suppliers }\end{array}$ & $\begin{array}{l}\text { Intervention: } \\
\text { FC united two suppliers for } \\
\text { problem solving }\end{array}$ & $\begin{array}{l}\text { Intervention: } \\
\text { FC united two suppliers for } \\
\text { problem solving }\end{array}$ \\
\hline & $\begin{array}{l}\text { Delegation: } \\
\text { Where not intervening } \\
\text { companies left } \\
\text { communication to suppliers }\end{array}$ & $\begin{array}{l}\text { Delegation: } \\
\text { FC encouraged } \\
\text { communication amongst two } \\
\text { suppliers }\end{array}$ & $\begin{array}{l}\text { Delegation: } \\
\text { FC encouraged } \\
\text { communication amongst } \\
\text { suppliers \& involved indirect } \\
\text { suppliers in problem solving }\end{array}$ \\
\hline $\begin{array}{l}\text { Dominant } \\
\text { strategy }\end{array}$ & $\begin{array}{l}\text { Strong direct intervention } \\
\text { from vehicle assembler }\end{array}$ & $\begin{array}{l}\text { Combined indirect } \\
\text { intervention \& explicit } \\
\text { delegation }\end{array}$ & $\begin{array}{l}\text { Combined intervention \& } \\
\text { explicit delegation }\end{array}$ \\
\hline
\end{tabular}

FC: Focal Company 